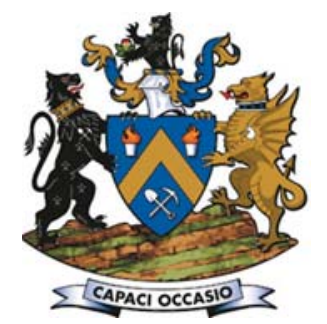

\title{
Thermodynamic evaluation of Sr- containing Si metals and silicate melts for Si-Sr alloy production
}

\author{
by K. Tang*, L.K. Jakobsson ${ }^{\dagger}$, and K. Hildal ${ }^{\dagger}$
}

\section{Synopsis}

Reliable thermodynamic descriptions of the Si-based $\mathrm{Sr}-\mathrm{Al}-\mathrm{Ca}-\mathrm{Fe}-\mathrm{Mg}$ metal system and $\mathrm{SiO}_{2}-\mathrm{SrO}-\mathrm{CaO}-\mathrm{MgO}-\mathrm{Al}_{2} \mathrm{O}_{3}$ oxide system are essential for the understanding and optimizing the production of Si-Sr alloys. Phase relations of all SrO containing binary and ternary subsystems were evaluated and thermodynamically modelled based on the existing literature data. Phase equilibria in the $\mathrm{SiO}_{2}$-SrO-CaO-MgO- $\mathrm{Al}_{2} \mathrm{O}_{3}$ higher-order oxide system were thus possible to calculate by the CALPHAD method. A thermodynamic description of the $\mathrm{Si}-\mathrm{Sr}-\mathrm{Al}-\mathrm{Ca}-\mathrm{Fe}-\mathrm{Mg}$ metal system was developed based on assessment of all binary systems as well as all Si containing ternary subsystems. The newly developed thermochemical databases can be used to calculate the equilibrium distribution of $\mathrm{Sr}$ between metal and slag. The theoretical Sr distribution maps for both pure Si and 75FeSi alloys in different SrO-containing slags are reported.

\section{Keywords}

thermodynamic evaluation, $\mathrm{Si}-\mathrm{Sr}-\mathrm{Al}-\mathrm{Ca}-\mathrm{Fe}-\mathrm{Mg}$ metal, $\mathrm{SiO}_{2}$-SrO-CaO-MgO$\mathrm{Al}_{2} \mathrm{O}_{3}$ oxide, $\mathrm{Sr}$ equilibrium distribution.

\section{Introduction}

Strontium distribution equilibria between the Si-based metals and Sro-containing silicate melts are of great importance for the development of new ferrosilicon products. To describe the complex phase equilibria between the Sr-containing Si metals and silicate slags, thermodynamic descriptions of the Srcontaining metal and oxide phases are essential. This paper summarizes our recent work on thermodynamic modelling of the Sirich $\mathrm{Si}-\mathrm{Sr}-\mathrm{Al}-\mathrm{Ca}-\mathrm{Fe}-\mathrm{Mg}$ metal and $\mathrm{SiO}_{2}-\mathrm{SrO}$ $\mathrm{CaO}-\mathrm{MgO}-\mathrm{Al}_{2} \mathrm{O}_{3}$ oxide systems.

Thermochemical descriptions of the above metal and oxide phases were input into databases for the FactSage ${ }^{\mathrm{TM}}$ software package. The model calculations for the phase equilibrium relations in the $\mathrm{SiO}_{2}-\mathrm{SrO}_{-}-\mathrm{Al}_{2} \mathrm{O}_{3}$ ternary oxide system were verified by laboratory experiments. The metal/slag strontium distribution equilibria at elevated temperatures were then evaluated thermodynamically. The present equilibrium simulations can serve as a 'map' for the metallurgist to design and optimize $\mathrm{Si}-\mathrm{Sr}$ ferroalloy production.

\section{Thermodynamic assessments}

\section{The metal system}

Thermodynamic descriptions of the liquid and solid Si-based Si-Al-Ca-Sr-Fe-Mg alloy phases have been set up based mainly on the experimental data available in the literature. The compound energy formalism is applied to liquid and all the mixture phases as well as stoichiometric compounds.

The six-element metal system contains 15 binary, 20 ternary, 15 quaternary, and 6 quinary subsystems. Since the metal system is in the Si-rich domain, the Si-free ternary and higher-order subsystems are not considered in the present study. To ensure the reliability of the model calculation, all 15 binary subsystems were modelled to cover the whole composition range, and temperatures from the liquid phase to the sub-liquidus solid phases.

The calculated Sr-Si binary phase diagram, based on the assessment of Li et al. (2011), is shown in Figure 1. Experimental phase equilibrium data reported by Palenzona and Pani (2004) and Rygalin et al. (2010) is also shown in the diagram. The assessment emphasized the eutectic and peritectic reaction temperatures and compositions.

The experimental Sr-Al phase equilibria reported by Closset and Gruzleski (1982), Vakhobov, Eshonov, and Dzhurayev (1979), and Bruzzone and Merlo (1975) can be reproduced using the model parameters assessed by Zhong et al. (2004). The calculated phase diagram is shown in Figure 2.

The Ca-Sr phase diagram, assessed by the present authors based on the experimental liquidus and solidus data by Schottmiller,

\footnotetext{
* SINTEF Industry, Norway.

Elkem Technology, Norway.

(C) The Southern African Institute of Mining and Metallurgy, 2018. ISSN 2225-6253. This paper was first presented at the INFACON XV:

International Ferro-Alloys Congress, 25-28

February 2018, Century City Conference Centre and Hotel, Cape Town, South Africa
} 


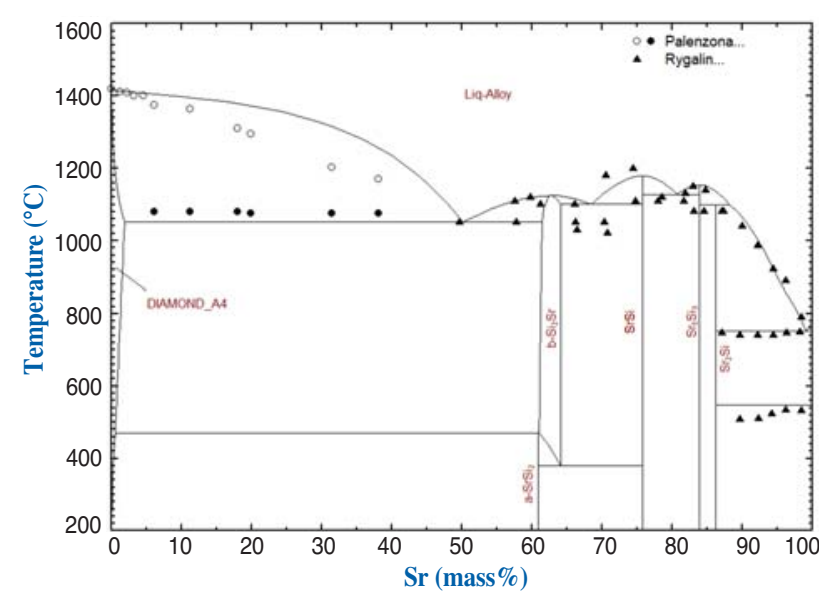

Figure 1-Calculated Si-Sr binary phase diagram (after Li et al., 2011)

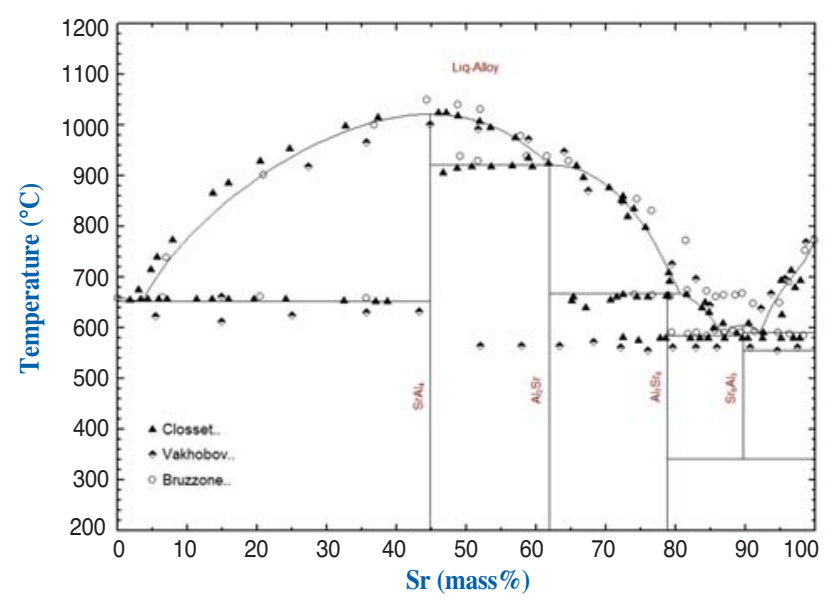

Figure 2-Calculated Sr-Al binary phase diagram (after Zhong et al., 2004)

King, and Kanda (1958) is shown in Figure 3. These three binary subsystems, together with the Sr-Fe binary, are of great importance for the phase equilibria and elemental distributions of Sr-containing alloys.

There exist 10 Si-containing ternary subsystems which are also very important for the present thermodynamic descriptions, as shown in Table I. Only a few ternary systems have been thermodynamically assessed in the literature. Since the Sr concentrations in pure Si and FeSi alloys are in the range of dilute solution, i.e. $<5 \mathrm{wt} \%$, ternary and higherorder contributions to the melts will not be significant. This means that the present database can represent thermochemical properties of the Si-based Sr-Al-Ca-Fe-Mg alloys at elevated temperatures.

The calculated $\mathrm{Al}-\mathrm{Al}_{2} \mathrm{Si}_{2} \mathrm{Sr}$ pseudo-binary phase diagram is shown in Figure 4. In this ternary alloy system, the model calculation can reproduce the experimental phase boundaries (Sato et al., 1985) quite well. The agreement between the calculated and measured phase equilibria by Vakhobov, Eshonov, and Dzhurayev (1979) is also satisfactory in the low-Sr composition domain.

Thermodynamic model calculations for the phase equilibria in the $\mathrm{Si}-\mathrm{Mg}$-Sr ternary as well as in the $\mathrm{Si}-\mathrm{Al}-\mathrm{Ca}$ -

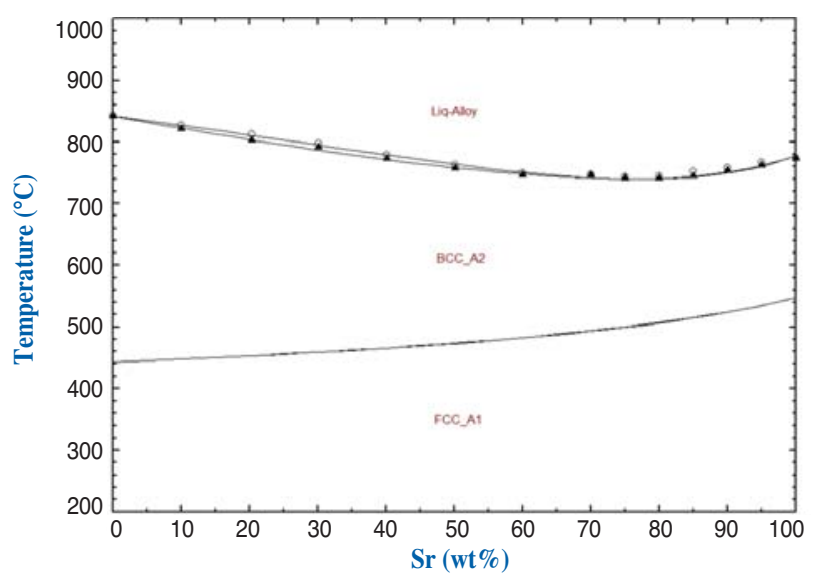

Figure 3-Calculated Ca-Sr binary phase diagram

\section{Table I}

Ternary subsystems used in the present database

\begin{tabular}{|c|c|c|c|c|}
\hline No. & \multicolumn{3}{|c|}{ System } & References \\
\hline 1 & $\mathrm{Si}$ & Al & $\mathrm{Sr}$ & $\begin{array}{c}\text { Sato et al. (1985), Vakhobov, Ganiev, } \\
\text { and Djuraev (1975), Janz and } \\
\text { Schmid-Fetzer (2009) }\end{array}$ \\
\hline 2 & $\mathrm{Si}$ & $\mathrm{Ca}$ & $\mathrm{Sr}$ & No ref. \\
\hline 3 & $\mathrm{Si}$ & $\mathrm{Fe}$ & $\mathrm{Sr}$ & No ref. \\
\hline 4 & $\mathrm{Si}$ & $\mathrm{Mg}$ & $\mathrm{Sr}$ & $\begin{array}{l}\text { Rokhlin and Dobatkina (2001), } \\
\text { Gil-Santos et al. (2016) }\end{array}$ \\
\hline 5 & $\mathrm{Si}$ & $\mathrm{Al}$ & $\mathrm{Ca}$ & $\begin{array}{l}\text { Effenberg and llyenko (2004), Anglezio, } \\
\text { Servant, and Ansara (1994a, 1994,) }\end{array}$ \\
\hline 6 & $\mathrm{Si}$ & $\mathrm{Al}$ & $\mathrm{Fe}$ & Anglezio, Servant, and Ansara (1994a, 1994b) \\
\hline 7 & $\mathrm{Si}$ & $\mathrm{Ca}$ & $\mathrm{Fe}$ & Anglezio, Servant, and Ansara (1994a, 1994b) \\
\hline 8 & $\mathrm{Si}$ & $\mathrm{Mg}$ & $\mathrm{Fe}$ & Duo et al. (2007) \\
\hline 9 & $\mathrm{Si}$ & $\mathrm{Ca}$ & $\mathrm{Mg}$ & $\begin{array}{c}\text { Gröbner, Chumak, and Schmid-Fetzer (2003), } \\
\text { Rokhlin, Evgeniya Lysova, and Materials } \\
\text { Science International Team (2000) }\end{array}$ \\
\hline 10 & $\mathrm{Si}$ & $\mathrm{Al}$ & $\mathrm{Mg}$ & Tang et al. (2012, Feufel et al. (1997) \\
\hline
\end{tabular}

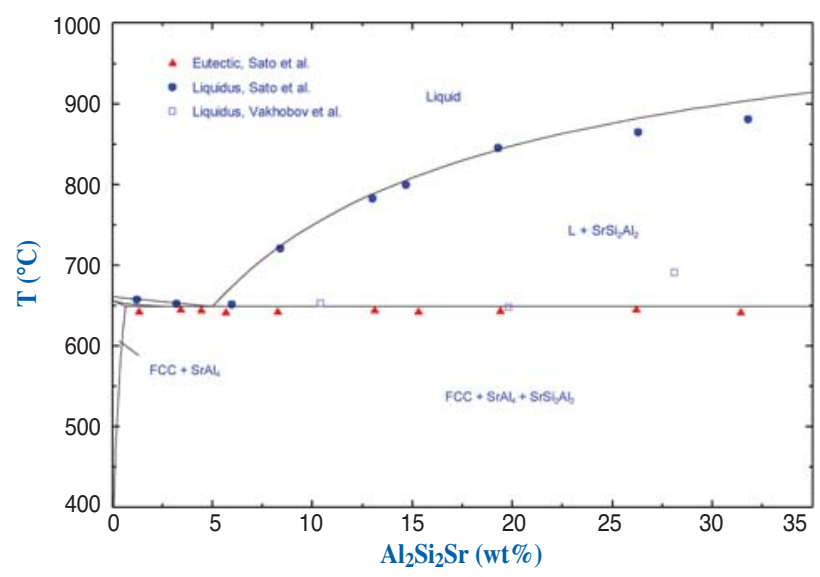

Figure 4-Calculated $\mathrm{Al}-\mathrm{Al}_{2} \mathrm{Si}_{2} \mathrm{Sr}$ pseudo-binary phase diagram

Fe quaternary system were also examined with the experimental data in the literature. For the sake of simplicity, they are not presented here. 


\section{Thermodynamic evaluation of Sr-containing Si metals and silicate melts for Si-Sr alloy production}

Thermodynamic properties of the Si-Sr-Al-Ca-Fe-Mg system are all extrapolated from the above assessed binaries and some ternaries, as well as Si-Al-Ca-Fe quaternary subsystems.

\section{Oxide systems}

The $\mathrm{SiO}_{2}-\mathrm{CaO}-\mathrm{Al}_{2} \mathrm{O}_{3}$-SrO-MgO oxide system consists of 10 binaries and 10 ternaries. Unlike the Si-rich metals, the slags vary over a large composition range. It is thus necessary to evaluate whole binary and ternary oxide subsystems in their entirety. To define the oxide equilibrium contents, both the liquid slag and solid oxide phases need to be correctly modelled. In the present work, the molten slag phase was modelled using the modified quasichemical solution model (Pelton and Blander, 1986). Solid non-stochiometric phases, for instance the monoxide phases, were modelled using the compound energy formalism.

Thermodynamic models of the $\mathrm{SrO}$-free $\mathrm{SiO}_{2}-\mathrm{CaO}-\mathrm{Al}_{2} \mathrm{O}_{3}-$ $\mathrm{MgO}$ oxide system can be found in the literature. Four SrOcontaining binary and three SrO-containing ternary subsystems were modelled in the present work. Table II lists the binary oxide subsystems used.

The liquid $\mathrm{SiO}_{2}$-SrO phase was assessed based on the phase equilibrium data available in the literature (Fields, Dear, and Brown, 1972; Hageman and Oonk, 1986; Huntelaar, Cordfunke, and Ouweltjes, 1992; Ghanbari-Ahari and Brett, 1988). All solid mixture phases in the present work are treated as stoichiometric compounds.

The experimental phase equilibria data related to liquid $\mathrm{SrO}-\mathrm{Al}_{2} \mathrm{O}_{3}$ slag were mainly based on the experimental results of Hanic, Chemekova, and Udalov (1979) and Starczewski (1964). The present assessment was based on the experimental data of Starczewski (1964). The calculated SrO- $\mathrm{Al}_{2} \mathrm{O}_{3}$ phase diagram is shown in Figure 6 . The model calculations fit the experimental equilibrium data by Starczewski (1964), since his data fits well to the $\mathrm{SrO}_{-} \mathrm{SiO}_{2-}$ $\mathrm{Al}_{2} \mathrm{O}_{3}$ ternary phase equilibria.

Phase equilibria in the $\mathrm{SrO}-\mathrm{SiO}_{2}-\mathrm{Al}_{2} \mathrm{O}_{3}$ system are of crucial importance for the determination of the Sr distribution between slag and metal. There are three ternary compounds reported by Dear (1957), namely $\mathrm{Si}_{2} \mathrm{SrAl}_{2} \mathrm{O}_{8}, \mathrm{Si}_{2} \mathrm{Sr}_{6} \mathrm{Al}_{18} \mathrm{O}_{37}$, and $\mathrm{SiSr}_{2} \mathrm{Al}_{2} \mathrm{O}_{7}$. Thermodynamic properties of these compounds were also reported in the literature (Lapina, Semenov, and Khodakovskii, 1989; Massazza and Sirchia, 1959). Based on the literature data, properties of these ternary compounds were estimated.

Table II

Binary subsystems used in the present database

\begin{tabular}{|l|c|c|c|}
\hline No. & \multicolumn{2}{|c|}{ System } & Reference \\
\hline 1 & $\mathrm{SiO}_{2}$ & $\mathrm{SrO}$ & This work \\
2 & $\mathrm{SiO}_{2}$ & $\mathrm{Al}_{2} \mathrm{O}_{3}$ & Eriksson and Pelton (1993) \\
3 & $\mathrm{SiO}_{2}$ & $\mathrm{CaO}$ & Eriksson and Pelton (1993) \\
4 & $\mathrm{SiO}_{2}$ & $\mathrm{MgO}$ & Decterov, Jung, and Pelton (2002) \\
5 & $\mathrm{Al}_{2} \mathrm{O}_{3}$ & $\mathrm{CaO}$ & Eriksson and Pelton (1993) \\
6 & $\mathrm{Al}_{2} \mathrm{O}_{3}$ & $\mathrm{SrO}$ & This work \\
7 & $\mathrm{Al}_{2} \mathrm{O}_{3}$ & $\mathrm{MgO}$ & Jung, Decterov, and Pelton (2004a) \\
8 & $\mathrm{CaO}$ & $\mathrm{SrO}$ & This work \\
9 & $\mathrm{CaO}$ & $\mathrm{MgO}$ & Wu, Eriksson, and Pelton (1993) \\
10 & $\mathrm{MgO}$ & $\mathrm{SrO}$ & This work \\
\hline
\end{tabular}

The calculated liquidus projection of the $\mathrm{SiO}_{2}-\mathrm{SrO}-\mathrm{Al}_{2} \mathrm{O}_{3}$ ternary oxide system is shown in Figure 7 . It is seen that this ternary system is similar to the well-known $\mathrm{SiO}_{2}-\mathrm{CaO}-\mathrm{Al}_{2} \mathrm{O}_{3}$ ternary system. Two SrO-containing compounds precipitate in the middle of the composition range, where the slags exhibit low smelting temperatures.

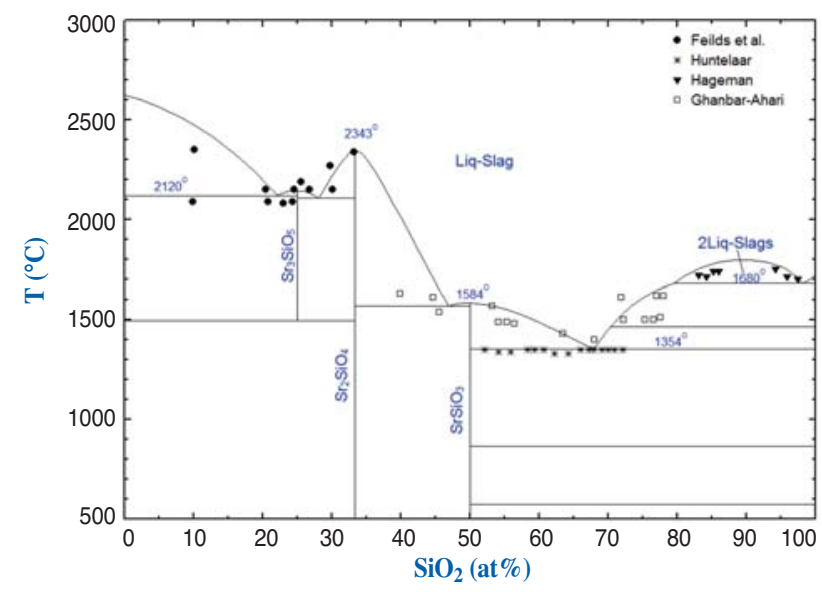

Figure 5-Calculated $\mathrm{SiO}_{2}-\mathrm{SrO}$ phase diagram

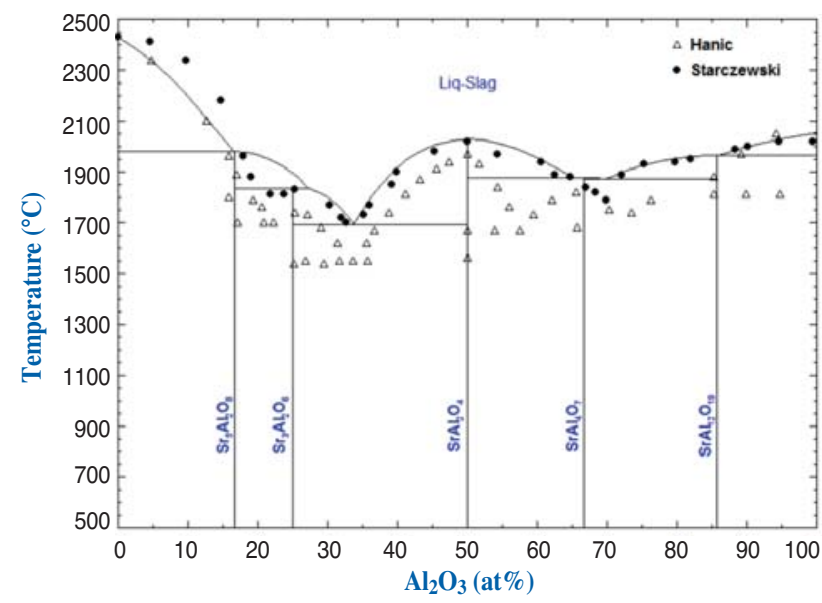

Figure 6-Calculated $\mathrm{Al}_{2} \mathrm{O}_{3}-\mathrm{SrO}$ phase diagram

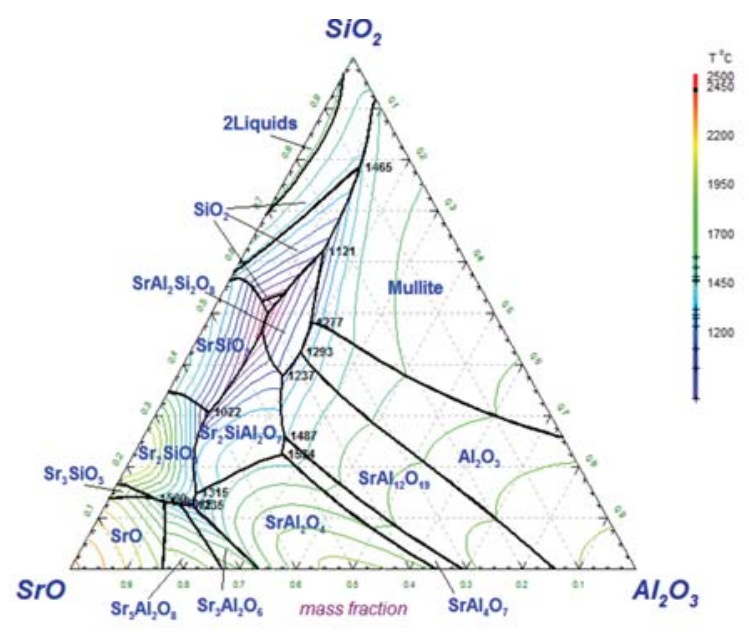

Figure 7-Calculated liquidus projection of the $\mathrm{SiO}_{2}-\mathrm{Al}_{2} \mathrm{O}_{3}-\mathrm{SrO}$ system 


\section{Thermodynamic evaluation of Sr-containing Si metals and silicate melts for Si-Sr alloy production}

For the sake of simplicity, detailed descriptions of the experimental data as well as model assessment will not be presented here. The information related to other ternary oxide subsystems is summarized in Table III.

\section{Slag/metal equilibria}

The slag/metal Sr partition equilibria are the most interesting aspect of the present study. The partition of $\mathrm{Sr}$ between $\mathrm{Si}-\mathrm{Sr}$ metals and $\mathrm{SrO}_{-} \mathrm{SiO}_{2}$ binary slags at different temperatures is shown in Figure 8. The Sr distribution equilibria between $75 \mathrm{FeSi}$ alloys and $\mathrm{SrO}_{-} \mathrm{SiO}_{2}$ binary slags at $1600^{\circ} \mathrm{C}$ are also shown in the same diagram.

It is notable that the $\mathrm{Sr}$ contents in $75 \mathrm{FeSi}$ are about 10 times lower than those in Si metals. This is due to the strong positive interaction between $\mathrm{Fe}$ and $\mathrm{Sr}$, which can also be observed by the immiscibility of $\mathrm{Fe}$ and $\mathrm{Sr}$.

Figure 9 shows the iso-Sr composition contours for pure $\mathrm{Si}$ in equilibrium with the ternary $\mathrm{SiO}_{2}-\mathrm{SrO}-\mathrm{Al}_{2} \mathrm{O}_{3}$ slags at $1600^{\circ} \mathrm{C}$. The amphoteric property of $\mathrm{Al}_{2} \mathrm{O}_{3}$ is rather obvious, i.e. $\mathrm{Al}_{2} \mathrm{O}_{3}$ acts as a basic oxide in the $\mathrm{SiO}_{2}$-rich area and an acid oxide in the SrO-rich domain. Figure 10 shows the similar equilibrium iso-Sr contours for the same system at $1700^{\circ} \mathrm{C}$.

By comparing Figure 10 to Figure 9, we see that temperature does not play a key role in the Sr partition equilibria in this ternary slag system. This means that the silicothermic reduction of $\mathrm{SrO}$ is relatively independent of temperature. However, slag composition plays a vital role in the $\mathrm{Sr}$ contents in Si metals, in particular for the higher SrO slags. By increasing the SrO content in the slag from $55 \mathrm{wt} \%$ to $60 \mathrm{wt} \%$, the final equilibrium Sr content in Si will increase from around 6-7 wt\% to $18-31 \mathrm{wt} \%$ at $1600-1700^{\circ} \mathrm{C}$.

The present thermodynamic models can also be used to evaluate the solidification of Si/75FeSi alloys, smelting behaviour of SrO-containing slags, as well as materials and energy balances during metallurgical processes. This will be discussed in our next publication.

\section{Conclusions}

Thermodynamic descriptions of the Si-based $\mathrm{Sr}-\mathrm{Al}-\mathrm{Ca}-\mathrm{Fe}-\mathrm{Mg}$ metal and $\mathrm{SiO}_{2}-\mathrm{SrO}-\mathrm{CaO}-\mathrm{MgO}-\mathrm{Al}_{2} \mathrm{O}_{3}$ oxide systems have been established and implemented in the commercial software package FactSage. Thermodynamic modelling of the Si-based Si-Sr-Al-Ca-Fe-Mg metal system was developed based on assessments of all binary systems as well as the SiSr-Al, Si-Sr-Mg, Si-Al-Mg ternary, and Si-Al-Ca-Fe quaternary subsystems.

\section{Table III}

\section{Ternary subsystems used in the present database}

\begin{tabular}{|l|c|c|c|c|}
\hline No. & \multicolumn{3}{|c|}{ System } & Reference \\
\hline 1 & $\mathrm{SiO}_{2}$ & $\mathrm{Al}_{2} \mathrm{O}_{3}$ & $\mathrm{CaO}$ & Eriksson and Pelton (1993) \\
2 & $\mathrm{SiO}_{2}$ & $\mathrm{Al}_{2} \mathrm{O}_{3}$ & $\mathrm{SrO}$ & This work \\
3 & $\mathrm{SiO}_{2}$ & $\mathrm{Al}_{2} \mathrm{O}_{3}$ & $\mathrm{MgO}$ & Jung, Decterov, and Pelton (2004b) \\
4 & $\mathrm{SiO}_{2}$ & $\mathrm{CaO}$ & $\mathrm{SrO}$ & This work \\
5 & $\mathrm{SiO}_{2}$ & $\mathrm{MgO}$ & $\mathrm{SrO}$ & This work \\
6 & $\mathrm{Al}_{2} \mathrm{O}_{3}$ & $\mathrm{CaO}$ & $\mathrm{SrO}$ & This work \\
7 & $\mathrm{Al}_{2} \mathrm{O}_{3}$ & $\mathrm{CaO}$ & $\mathrm{MgO}$ & Jung, Decterov, and Pelton (2004b) \\
8 & $\mathrm{CaO}_{2}$ & $\mathrm{MgO}$ & $\mathrm{SrO}$ & This work \\
9 & $\mathrm{Al}_{2} \mathrm{O}_{3}$ & $\mathrm{MgO}$ & $\mathrm{SrO}$ & This work \\
\hline
\end{tabular}

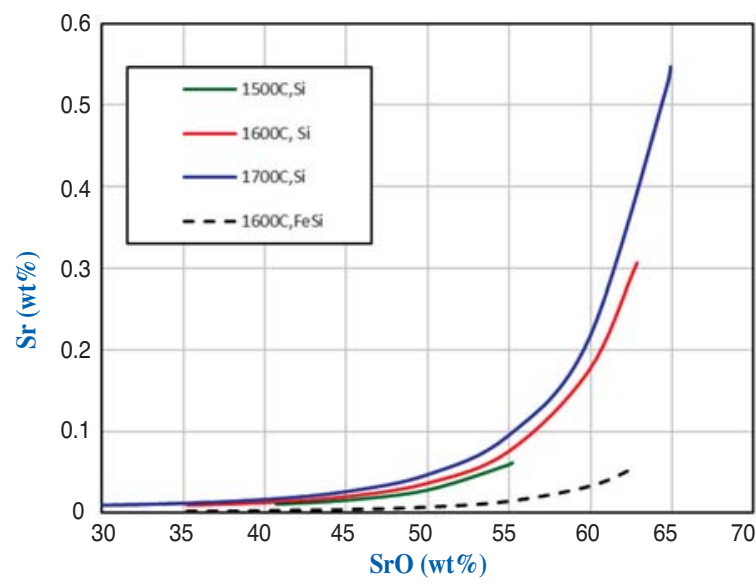

Figure 8-Calculated $\mathrm{Sr}$ distribution between $\mathrm{Si} 75 \mathrm{FeSi}$ and $\mathrm{SiO}_{2}-\mathrm{SrO}$ slag at different temperatures

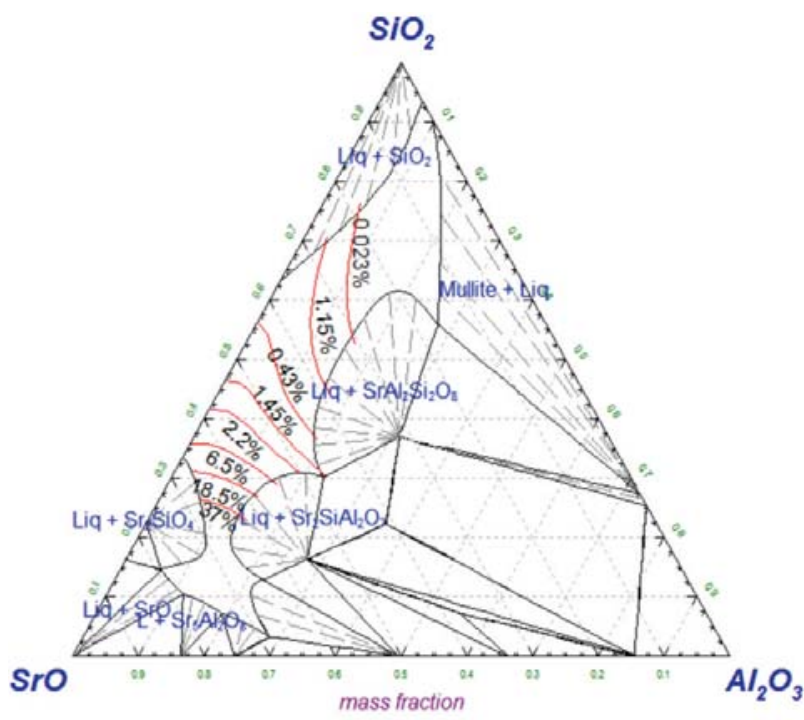

Figure 9-Calculated iso-Sr composition lines in $\mathrm{Si}$ metals represented in the $\mathrm{SiO}_{2}-\mathrm{SrO}-\mathrm{Al}_{2} \mathrm{O}_{3}$ ternary system at $1600^{\circ} \mathrm{C}$

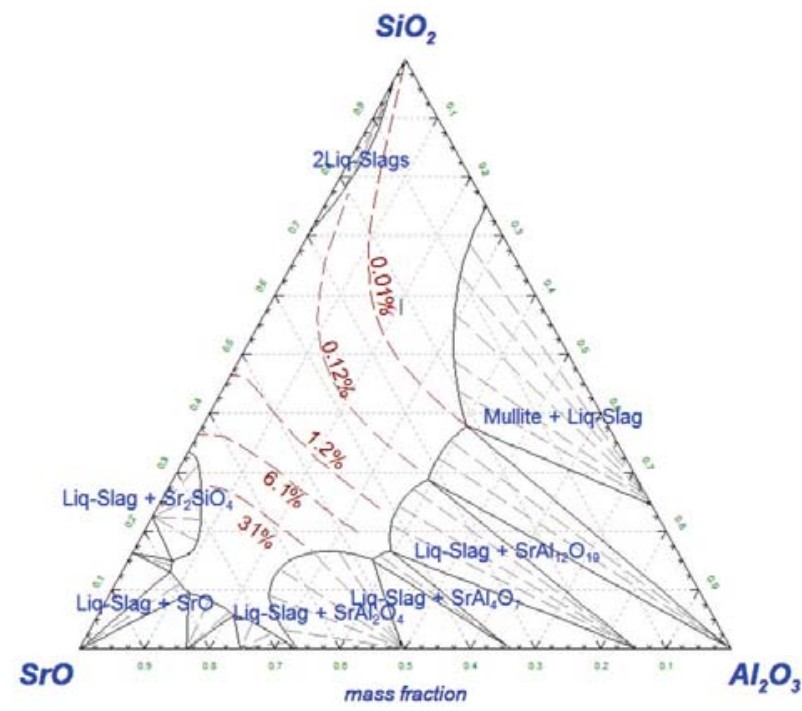

Figure 10-Calculated iso-Sr composition lines in Si metals represented in the $\mathrm{SiO}_{2}-\mathrm{SrO}_{-}-\mathrm{Al}_{2} \mathrm{O}_{3}$ ternary system at $1700^{\circ} \mathrm{C}$ 


\section{Thermodynamic evaluation of Sr-containing Si metals and silicate melts for Si-Sr alloy production}

Phase relations in the $\mathrm{SiO}_{2}-\mathrm{SrO}, \mathrm{SrO}-\mathrm{Al}_{2} \mathrm{O}_{3}$ binary as well as the $\mathrm{SiO}_{2}-\mathrm{SrO}-\mathrm{Al}_{2} \mathrm{O}_{3}, \mathrm{SiO}_{2}-\mathrm{SrO}-\mathrm{CaO}$, and $\mathrm{SiO}_{2}-\mathrm{SrO}-\mathrm{MgO}$ ternary system were evaluated and thermodynamically modelled based on existing literature data. Phase equilibria in the $\mathrm{SiO}_{2}$-SrO-CaO-MgO- $\mathrm{Al}_{2} \mathrm{O}_{3}$ higher-order oxide system were thus possible to calculate by the CALPHAD method.

The thermochemical databases have been applied to evaluate the $\mathrm{Sr}$ distribution equilibria between pure $\mathrm{Si}$ and $\mathrm{SiO}_{2}$-SrO slags as well as $\mathrm{FeSi}$ and $\mathrm{SiO}_{2}$-SrO slags. In addition, the equilibrium distribution of $\mathrm{Sr}$ between pure silicon and $\mathrm{SiO}_{2}-\mathrm{SrO}-\mathrm{CaO}-\mathrm{Al}_{2} \mathrm{O}_{3}$ slags was calculated. It is found that the $\mathrm{Sr}$ contents in Si metals are much higher than those in $75 \mathrm{FeSi}$ alloys. The $\mathrm{Sr}$ contents in Si metals will depend strongly upon the slag composition, and weakly upon the temperature.

\section{Acknowledgements}

This work was supported by the Research Council of Norway through the project CoRReSi (project number: 235159/030).

\section{References}

Anglezio, J.C., Servant, C., and Ansara, I. 1994a. Contribution to the experimental and thermodynamic assessment of the Al-Ca-Fe-Si system. I.Al-Ca-Fe, Al-Ca-Si, Al-Fe-Si and Ca-Fe-Si systems. Calphad - Computer Coupling of Phase Diagrams and Thermochemistry, vol. 18. pp. 273-309.

Anglezio, J.C., Servant, C., and Ansara, I. 1994b. A study of the Si-rich domain of the Al-Ca-Fe-Si quaternary system. Calphad - Computer Coupling of Phase Diagrams and Thermochemistry, vol. 18. pp. 311-318.

Bruzzone, G. and MerLo, F. 1975. The strontium-aluminium and bariumaluminium systems. Journal of the Less Common Metals, vol. 39. pp. 1-6.

Closset, B. and GruzLeski, J.E. 1982. Structure and properties of hypoeutectic Al-Si-Mg alloys modified with pure strontium. Metallurgical Transactions A, vol. 13. pp. 945-951.

DEAR, P.S. 1957. Sub-liquidus equilibria for the ternary system $\mathrm{SrO}-\mathrm{Al}_{2} \mathrm{O}_{3}$ $\mathrm{SiO}_{2}$. Virginia Polytechnic Institute, Blacksburg, VA

Decterov, S., Jung, I-H., and Pelton, A.D. 2002. Thermodynamic modeling of the $\mathrm{FeO}-\mathrm{Fe}_{2} \mathrm{O}_{3}-\mathrm{MgO}-\mathrm{SiO}_{2}$ system. Journal of the American Ceramic Society, vol. 85. pp. 2903-3910.

Duo, Y., Zhao, J.R., Zhang, C., Chen, H.L., and Zhang, L.J. 2007. Thermodynamic modeling of the Fe-Mg-Si system. Journal of Mining and Metallurgy Section B - Metallurgy, vol. 43. pp. 39-56.

EFFenberg, G. and Ilyenko, S. 2004. Al-Ca-Si (aluminium - calcium - silicon). Light Metal Systems. Part 1: Selected Systems from Ag-Al-Cu to Al-Cu-Er. Springer, Berlin/Heidelberg.

Eriksson, G. and Pelton, A.D. 1993. Critical evaluation and optimization of the thermodynamic properties and phase-diagrams of the $\mathrm{CaO}-\mathrm{Al}_{2} \mathrm{O}_{3}, \mathrm{Al}_{2} \mathrm{O}_{3}$ $\mathrm{SiO}_{2}$, and $\mathrm{CaO}-\mathrm{Al}_{2} \mathrm{O}_{3}-\mathrm{SiO}_{2}$ systems. Metallurgical Transactions $B$ - Process Metallurgy, vol. 24. pp. 807-816.

Feufel, H., Gödecke, T., LuKAS, H.L., and Sommer, F. 1997. Investigation of the $\mathrm{Al}-\mathrm{Mg}$-Si system by experiments and thermodynamic calculations. Journal of Alloys and Compounds, vol. 247. pp. 31-42.

Fields, J., PAul, M., Dear, S., and Brown, J.J. 1972. Phase equilibria in the system BaO-SrO-SiO ${ }_{2}$. Journal of the American Ceramic Society, vol. 55. pp. 585-588.

GHANBARI-AHARI, K. and BRETT, N.H. 1988. Phase equilibria and microstructure in the system zirconia-magnesia-silica-strontia. Part 2: The ternary system magnesia-silica-strontia. British Ceramic Transactions, vol. 87. pp. 103-106.

Gil-Santos, A., Moelans, N., Hort, N., and van der Biest, O. 2016. Identification and description of intermetallic compounds in $\mathrm{Mg}$-Si-Sr cast and heat-treated alloys. Journal of Alloys and Compounds, vol. 669. pp. 123-133.

GröBner, J., Chumak, I., and Schmid-FetZer, R. 2003. Experimental study of ternary $\mathrm{Ca}-\mathrm{Mg}$-Si phase equilibria and thermodynamic assessment of $\mathrm{Ca}-$ Si and Ca-Mg-Si systems, Intermetallics, vol. 11. pp. 1065-74.
Hageman, V.B.M. and Oonk, H.A.J. 1986. liquid immiscibility in the $\mathrm{SiO}_{2}+$ $\mathrm{MgO}, \mathrm{SiO}_{2}+\mathrm{SrO}, \mathrm{SiO}_{2}+\mathrm{La}_{2} \mathrm{O}_{3}$, and $\mathrm{SiO}_{2}+\mathrm{Y}_{2} \mathrm{O}_{3}$ systems. Physics and Chemistry of Glasses, vol. 27. pp. 194-98.

HANic, F., CHEMEKova, T.Y., and UdAlov, Y.P. 1979. Strontium oxide-alumina system. Russian Journal of Inorganic Chemistry (Zhurnal Neorganicheskoi Khimii), vol. 24. pp. 471-475.

HuntelaAR, M.E., CoRDFunKe, E.H.P., and Ouweltjes, W. 1992. The standard molar enthalpies of formation of $\mathrm{SrSiO}_{3}(\mathrm{~s})$ and $\mathrm{Sr}_{2} \mathrm{SiO}_{4}(\mathrm{~s})$. Journal of Chemical Thermodynamics, vol. 24. pp. 139-143.

Janz, A. and Schmid-Fetzer, R. 2009. Thermodynamics and constitution of MgAl-Ca-Sr-Mn Alloys: Part I. Experimental investigation and thermodynamic modeling of subsystems $\mathrm{Mg}$-Ca-Sr and Al-Ca-Sr. Journal of Phase Equilibria and Diffusion, vol. 30. pp. 146-156.

Jung, I.H., Decterov, S.A., and Pelton, A.D. 2004a. Critical thermodynamic evaluation and optimization of the $\mathrm{MgO}-\mathrm{Al}_{2} \mathrm{O}_{3}, \mathrm{CaO}-\mathrm{MgO}-\mathrm{Al}_{2} \mathrm{O}_{3}$, and $\mathrm{MgO}-\mathrm{Al}_{2} \mathrm{O}_{3}-\mathrm{SiO}_{2}$ systems. Journal of Phase Equilibria and Diffusion, vol. 25. pp. 329-345.

Jung, I-H., Decterov, S.A., and Pelton, A.D. 2004b. Critical thermodynamic evaluation and optimization of the $\mathrm{MgO}-\mathrm{Al}_{2} \mathrm{O}_{3}, \mathrm{CaO}-\mathrm{MgO}-\mathrm{Al}_{2} \mathrm{O}_{3}$, and $\mathrm{MgO}-\mathrm{Al}_{2} \mathrm{O}_{3}-\mathrm{SiO}_{2}$ systems. Journal of Phase Equilibria and Diffusion, vol. 25. pp. 329-345.

Lapina, I.V., Semenov, Y.V., and KHodakovski, I.L. 1989. Thermodynamic properties of calcium-, strontium-, and barium feldspars based on calorimetric data. Geokhimiya, vol. 7. pp. 1033-1032.

LI, K., Liu, S., SHA, C., and Du, Y. 2011. A thermodynamic reassessment of the Si-Sr system. Calphad, vol. 35. pp. 594-600.

MASSAZZA, F. and SIRCHIA, E. 1959. Equilibriums at the temperature of fusion in the ternary system $\mathrm{SrO}-\mathrm{Al}_{2} \mathrm{O}_{3}$-CaO. Annali di Chimica, vol. 49 . pp. 1352-1370.

Palenzona, A. and Pani, M. 2004. The phase diagram of the Sr-Si system. Journal of Alloys and Compounds, vol. 373. pp. 214-219.

Pelton, A.D. and Blander, M. 1986. Thermodynamic analysis of ordered liquid solutions by a modified quasichemical approach-Application to silicate slags. Metallurgical Transactions B, vol. 17. pp. 805-815.

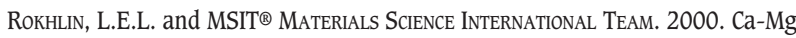
Si ternary phase diagram evaluation - Phase diagrams, crystallographic and thermodynamic data: MSI Eureka report 10.16786.1.7. Springer Materials. http://materials.springer.com/msi/docs/sm_msi_r_10_ 016786_01

RoкнLin, L. and DoваткіNA, T. 2001. Mg-Si-Sr ternary phase diagram evaluation. Ternary Evaluations. Effenberg, G. (ed.). MSI, Materials Science International Services, Stuttgart.

Rygalin, B., Prokofieva, V., Pavlova, L., and oкolov, Y.E.S. 2010. The Si-Sr and $\mathrm{Si}-\mathrm{Ba}$ phase diagrams over the Si-rich composition range. Calphad, vol. 34. pp. 196-199.

Sato, E., Kono, M., SAto, I., and Watanabe, H. 1985. Study on the phase diagram of Al-Si-Sr ternary alloy system. Journal of Japan Institute of Light Metals, vol. 35. pp. 71-78.

SchotTMiLler, J.C., KInG, A.J., and KANDA, F.A. 1958. The calcium-strontium metal phase system. Journal of Physical Chemistry, vol. 62. pp. 1446-1449.

StARCZEWSKI, M. 1964. Treatise on solid state reactions in the ternary system SrO- $-\mathrm{Al}_{2} \mathrm{O}_{3}-\mathrm{SiO}_{2}$. Zeszyty Naukowe Politechniki Slaskiej, Chemia, vol. 22. pp. 5-75.

TAng, Y., Du, Y., Zhang, L.J., Yuan, X.M., and KaPTAY, G. 2012. Thermodynamic description of the Al-Mg-Si system using a new formulation for the temperature dependence of the excess Gibbs energy. Thermochimica Acta, vol. 527. pp. 131-142.

VAKHoвov, A.V., Eshonov, K.K, and DzhuraYev, T.D. 1979. The Al-Sr-Nd phase diagram. Russian Metallurgy. pp. 167-172.

VAKновоv, A.V., GAniev, I.N., and DJuRAEv, T.D. 1975. IZV. Akad. Nauk. USSR Met., 15.

Wu, P., EriKsson, G., and Pelton, A.D. 1993. Critical evaluation and optimization of the thermodynamic properties and phase-diagrams of the $\mathrm{CaO}-\mathrm{FeO}, \mathrm{CaO}-\mathrm{MgO}, \mathrm{CaO}-\mathrm{MnO}$, FeO-MgO, FeO-MnO, and MgO-MnO sytems. Journal of the American Ceramic Society, vol. 76. pp. 2065-2075.

Zhong, Yu., Wolverton, C,. Austin Chang, Y., and Liu, Z-K. 2004. A combined CALPHAD/first-principles remodeling of the thermodynamics of Al-Sr: unsuspected ground state energies by 'rounding up the (un) usual suspects'. Acta Materialia, vol. 52. pp. 2739-2754. 